\title{
Incentives to provide local public goods: fiscal federalism, Russian style
}

\author{
Ekaterina V. Zhuravskaya ${ }^{\mathrm{a}, \mathrm{b}, *}$ \\ a Russian European Center for Economic Policy, Potapovsky Pereulok 5, building 4, \\ 101000 Moscow, Russia \\ ${ }^{\mathrm{b}}$ Stockholm Institute for Transition Economics, Stockholm, Sweden
}

\begin{abstract}
Based on a unique data set on Russian city budgets, this paper shows that revenue sharing between regional and local governments provides local governments with no incentive to increase tax base or provide public goods. Any change in local government's own revenues is almost entirely offset by changes in shared revenues. This leads to governmental over-regulation of private businesses. It is shown that fiscal incentives are a determinant of the formation of private business and the efficiency of public goods provision. The Russian federalism is compared to the Chinese federalism, where fiscal incentives reputedly are stronger in many provinces. (c) 2000 Elsevier Science S.A. All rights reserved.
\end{abstract}

Keywords: Federalism; Russia; Local government; Transition

JEL classification: H11; H41; H71; O57; P35

\section{Introduction}

The performance of the Russian economy stands in striking contrast to the performance of several other countries in Eastern Europe and Asia that have also undertaken economic reforms. Real Russian GDP had been declining for 8 years and stabilized in $1997^{1}$ for a short period of time, whereas Poland and China, for

*Tel.: +7-503-232-3613; fax: +7-503-232-3739.

E-mail address: zhuravsk@recep.glasnet.ru (E.V. Zhuravskaya)

${ }^{1}$ Source: Russian Economic Trends (1998). 
example, have benefited from continued high growth. This paper argues that inefficient inter-governmental relations are a possibly important reason why Russia lags behind other countries in economic growth. In particular, this paper provides evidence that the structure of revenue sharing between regional and local governments affects governments' incentives to foster business growth and to provide public goods efficiently.

I use a unique data set on Russian city budgets to show that any change in a local government's own revenues is almost entirely offset by an opposite change in shared revenues. Local governments are unable to benefit from an increase in the local tax base, and therefore lack a revenue incentive to expand the tax base. What are the consequences of the magnitude of fiscal incentives? I build a simple model to illustrate that if fiscal incentives are strong, i.e. if an increase in the local tax base results in a nearly equal increase in budgetary revenues, then governments bear financial costs in terms of foregone taxes when they over-regulate or restrict business. In contrast, if fiscal incentives are weak so that the local government's ability to increase its marginal revenue by increasing its tax base is close to zero, then budget revenues are not affected by changes in governmental policy towards business. Economically unjustified political intervention into business, such as excessive regulation, adversely influences entrepreneurial activity and lowers the governmental tax base. ${ }^{2}$ In a system with stronger local fiscal incentives, one should observe more benign regulation, and higher growth compared to a system with weaker fiscal incentives. In addition, stronger fiscal incentives should lead to higher efficiency in provision of public goods, because a smaller portion of public expenditures is wasted.

Having shown that fiscal incentives are weak in Russia on average, I empirically examine their consequences. Firstly, I provide some evidence that the strength of fiscal incentives affects private business formation. Secondly, I show that the efficiency of public spending at the local level increases with local fiscal incentives. For each city and year I gauge strength of fiscal incentives by a binomial indicator of the presence (or absence) of crowding-out of changes in own revenues by changes in shared revenues. I then estimate how the variation in the strength of fiscal incentives helps to predict variation in outcomes of public goods provision and formation of private businesses.

My approach rests on the theory of 'market-preserving federalism'. ${ }^{3}$ This literature stresses the importance of the government officials' fiscal and political incentives for economic growth. Contributors to this literature (e.g. Oi, 1992, 1994; Montinola et al., 1995; Qian and Weingast, 1996, 1997; Jin et al., 1999) argue that the Chinese fiscal reform of the early 1980s until 1994 gave local governments incentives to pursue local economic growth and possibly created a

\footnotetext{
${ }^{2}$ See Boycko et al. (1995) and Johnson et al. (1997).

${ }^{3}$ For a survey of this literature, see Qian and Weingast (1997).
} 
basis for China's remarkable economic performance. 'The importance of these new fiscal arrangements [in China] is that they induce a strong positive relationship between local revenue and local economic prosperity for all provinces and cities, thus providing local officials with incentive to foster that prosperity'. Other work on Chinese fiscal relations, however, has shown that such a strong relationship between economic performance of a locality and local budget revenue existed only in certain parts of China and not in others. ${ }^{6}$ The main result of this paper contrasts with the literature on Chinese federalism because it shows that the system of intergovernmental relations in Russia represents a model that deserves to be called 'market-hampering federalism' since local revenues are independent of local economic prosperity.

Shleifer (1997) argues that the economic difficulties of Russia's last decade are explained in part by the government's failure to provide institutions that promote business growth. He also provides some evidence of the predatory nature of local governments in Russia and discusses several theories of what determines government performance. In accord with Shleifer (1997), this paper lends support to the view that Russia's poor economic performance is explained to some extent by the lack of incentives for local governments to encourage business formation. Following the EBRD's (1997) Transition Report and Johnson et al. (1997), the evidence provided here suggests that the building of market-supporting institutions is an important requirement for a successful transition.

There has been extensive previous research on federal-regional fiscal relations in Russia. Treisman (1996a,b, 1997) has shown that federal grants are distributed purely according to political negotiation and do not follow economic objectives of the federal center. Lavrov (1996) has demonstrated that there is a vertical imbalance between the distribution of revenues and expenditure responsibilities: during recent years, regional governments have controlled a disproportionately high share of resources. There has been, however, a void in our understanding of regional-local relations. This paper describes the effects of de facto regional control over local finance.

The paper is organized as follows. Section 2 presents a comparison of some organizational details of the Chinese and Russian governments. Section 3 develops a simple model of fiscal incentives. Section 4 describes the data and the empirical methodology. Section 5 contains the empirical results. Section 6 presents a robustness check, while Section 7 concludes.

\footnotetext{
${ }^{4}$ In 1994, in China another major fiscal reform was introduced.

${ }^{5}$ Montinola et al. (1995, p. 64).

${ }^{6}$ Wong (1997) and Arora and Norregaard (1997).

${ }^{7}$ The use of the term 'fiscal federalism' here is somewhat unconventional, since it refers to the fiscal incentives of governments resulting from the system of revenue sharing between different levels of government.
} 


\section{Chinese vs. Russian intergovernmental relations}

In this section, I compare organizational structures of governments in China and Russia and argue that they have many similarities, but may differ substantially in revenue sharing schemes and the incentives created by these schemes.

Russia is a federal state. China is a decentralized authoritarian state that in terms of fiscal affairs functions like a federal state. 'There are formally five levels of government in China. ${ }^{10}$ As a result of a fiscal reform in the early 1980s (until 1994, the time of another major fiscal reform) the Chinese system of intergovernmental relations has achieved 'greater decentralization of fiscal authority, especially in terms of increasing autonomy of local governments over taxation'.

In Russia, there are also five levels of government. ${ }^{12}$ The top three levels formally are authorized to collect their own revenues and make decisions on expenditures. ${ }^{13}$ The first tier local governments became officially independent from the upper levels in 1991, and since 1993 the independence of the first tier local governments has been guaranteed by the Constitution. ${ }^{14}$

\subsection{Local expenditure responsibilities}

The distribution of expenditure responsibilities among levels of government is similar in China and Russia. In Russia, a third of total public spending takes place on the local level. ${ }^{15}$ In China, the sub-provincial share of total public spending was growing in the 1980 s and reached $47 \%$ in $1993 .^{16}$ Both in China and Russia expenditure responsibilities between different levels of government are poorly

\footnotetext{
${ }^{8}$ For institutional background on Chinese government, see Oi (1992), Qian and Xu (1993), Oi (1994), Montinola et al. (1995), Qian and Weingast (1996, 1997), Wong (1997), and Arora and Norregaard (1997).

${ }^{9}$ In both Russia and China prior to their fiscal reforms, local governments were formally just branches of the upper tiers of government and were administratively dependent on them.

${ }^{10}$ The Chinese levels of government are the following: (1) central, (2) provincial, (3) prefecture, (4) county or municipality, and (5) township or district.

${ }^{11}$ Arora and Norregaard (1997).

${ }^{12}$ The Russian levels of government are the following: (1) federal, (2) regional, (3) the 'first tier local', including cities and rayons, (4) the 'second tier local', including cities within rayons and districts within cities, and (5) the 'third tier local', including districts within cities within rayons.

${ }^{13}$ The lowest two tiers are branches of the first tier local governments and are directly subordinate to them. This paper studies only the first tier of local governments in Russia and I will refer to them as local governments.

${ }^{14}$ Russian fiscal reform started in 1991 and continues to this day.

${ }^{15}$ Appendix A contains a detailed example of the distribution of expenditures and revenues among the three levels of government in Russia in 1996.

${ }^{16}$ See Table 2 on p. 24 in Arora and Norregaard (1997) for distribution of expenditures between central and provincial governments and Table 1.8 on p. 56 in Wong (1997) for distribution of expenditures between different tiers of sub-national governments in China.
} 
defined. ${ }^{17}$ De facto local governments in both countries are responsible for providing some basic public goods, including pre-college education and most health care. ${ }^{18}$ They also provide garbage collection, local public transportation, some police protection, local road maintenance, etc. Finally, local governments subsidize loss-making enterprises. In Russia, the largest share of expenditures at the local level is subsidies to large industrial enterprises and utilities; in China, subsidies constitute a much smaller (although significant) portion of local budgets.

Regulatory authority over private business in both countries is concentrated at the local level. Local governments are responsible for licensing and registration of firms. ${ }^{19}$ Local authorities also rent out space to businesses and establish most of the regulations and fines. ${ }^{20}$ For example, health, fire, and other inspectors are subordinate to local government's offices and are financed out of local budgets.

\subsection{Local revenue sources}

Sources and structure of revenue for local governments are similar in the two countries as well. Local revenues consist of own and shared revenues in Russia and within-budget and off-budget revenues in China; the latter in turn are composed of extra-budgetary (EBF) and self-raised (SRF) funds. ${ }^{21}$ The local off-budget revenues in China and the local own revenues in Russia consist of: (1) various ad hoc local taxes, including license and other fees, and various surcharges and fines; and (2) non-tax revenues, which mostly come from municipal property leases, profits from municipal enterprises and TVEs, and privatization. ${ }^{22}$ The components of shared and within-budget revenues are (1) taxes shared with upper

\footnotetext{
${ }^{17}$ Wong (1997, p. 4), Federal law on the financial basis of local self government \#126-FZ-97, Budget code of Russian Federation \#145-FZ-98.

${ }^{18}$ Table 1 illustrates Russia's composition of local public expenditures in selected years. See Tables 4.7, 4.14, 4.17, 5.1, and 5.2, pp. 153-173 in Wong (1997) for Chinese composition of local public expenditures in selected counties and municipalities in selected years.

${ }^{19}$ The upper levels of government are responsible only for licensing for a number of special kinds of activities that have large externalities, e.g. chemical manufacturing.

${ }^{20}$ See Oi $(1992,1994)$ for details on China. For details on Russia see, for instance, Federal law on licensing \#158-FZ-98, President's Decree on registration of subjects of entrepreneurial activity \#1482-94, Federal Law on fire safety \#69-FZ-92, Federal Law on sanitary and epidemiological wellbeing of population \#5076-1-90, Government Resolutions on energy control \#938-98, communications control \#1156-93, technical control \#1291-93, and on transport inspections \#20-91, President's Decree on control over enforcement of labor legislation \#850-94. These federal laws delegate regulatory authority to the local level.

${ }^{21} \mathrm{~A}$ comprehensive description of off-budget funds in Chinese localities is provided by Wong (1997, pp. 200-209). Several alternative definitions of off-budget revenues are used in the literature. I stick to the definition from Wong (1997).

${ }^{22}$ For a detailed description of sources of off-budget revenues in China, see Table 5.23 in Wong (1997, p. 202), and Table 1 for sources of own revenues in Russia.
} 
levels of government, and (2) transfers (grants) from upper levels of government. ${ }^{23}$ 'Uses of EBF and SRF are virtually identical to those of budgetary revenues'. The same is true for uses of own and shared revenues in Russia.

The Chinese and Russian fiscal governmental structures look quite similar. In particular, the local governments in both countries have a certain level of autonomy in their decisions on taxation and expenditures. In addition, the sources of revenues and expenditure responsibilities of local governments in the two countries are analogous. ${ }^{25}$ There is one possibly important difference between the Chinese and Russian intergovernmental relations, however: the revenue sharing between different levels of government.

\subsection{Revenue sharing}

In China, there is a large diversity of revenue sharing arrangements. ${ }^{26} \mathrm{~A}$ common feature to revenue sharing in all of China is that a substantial part of revenues (off-budget revenues) are not subject to sharing. ${ }^{27}$ A widespread sharing arrangement for revenues within-budget is the following: a lower level of government enters into a long-term contract with the upper level of government on a total amount or a share of revenues to be remitted to the upper level for several years and the lower level of government keeps the remainder of the collections. ${ }^{28}$ There is extensive evidence on the magnitude of the marginal remittance rates for provincial within-budget revenues by the central government. Jin et al. (1999) report the mean marginal remittance rate of $16 \%$ of provincial revenue collection calculated using data on 29 provinces over the period of 1982 to 1992. In 1980, 10

\footnotetext{
${ }^{23}$ The relative importance of different sources of local revenues in Russia is described in Table 1. The relative importance of different sources of township revenues in China is given in Table 5.22 of Wong (1997, p. 200).

${ }^{24}$ Wong (1997, p. 203).

${ }^{25}$ Here I abstract from significant political differences in two of the countries, for instance, the dominance of the Communist party and the absence of elections at the sub-national levels of government in China (except at the village-level which is not a formal level of Chinese government) and consider only realized revenue sharing contracts.

${ }^{26}$ The description of revenue sharing in China given in this section applies to the time of the fiscal reform of the early 1980s up to 1994. A comprehensive study of the Chinese revenue sharing arrangements at the sub-provincial level is given in Wong (1997). For a description of revenue sharing between provinces and the center see Jin et al. (1999).

${ }^{27}$ At the township-level, off-budget revenues in China grew from $16.7 \%$ of total revenues in 1986 to $26.3 \%$ in 1993 (see Table 5.22, p. 200 in Wong (1997)). At the county-level, in the late 1970s, off-budget revenues were below $10 \%$ of total revenues; and in the early 1990s, they formed already approximately a half of total revenues (see Montinola et al., 1995). At the provincial level, extrabudgetary funds (not including SRF) grew from 31.77\% of the total in 1980 to $46.17 \%$ in 1992 (see Table 5, p. 18 in Knight and Li (1999)).

${ }^{28}$ See, for instance, Montinola et al. (1995) and Jin et al. (1999).
} 
out of 29 provinces had zero marginal remittance rates; by 1988, 26 out of 29 provinces had zero marginal remittance rates. ${ }^{29}$

Data on revenue sharing arrangements below the province-level is less systematic. The literature presents considerable anecdotal evidence. Wong (1997) reports that below the province-level of Chinese government there are some exceptions to the long-term revenue sharing rules. These exceptions are especially frequent at the township-level: 'sharing total revenues is the form [of sharing arrangements] most often applied to prosperous townships, and the sharing rate is set annually'. At the township level, however, there is an explicit official recognition of importance of non-budgetary sources (SRF and EBF) for financing government and creating revenue incentives. ${ }^{31}$

The decentralized nature of off-budget revenues of sub-national governments in China ensures local government security from predatory taxation by the upperlevel of government. ${ }^{32}$ Therefore, in most Chinese localities marginal remittance rates of the total revenues by the upper levels of government are quite low. This fact has motivated several authors to argue that between the 1980s and early 1990s China has become an instance of 'market-preserving federalism' since many local governments have become residual claimants of local tax base and, therefore, have gained strong incentives to maximize local revenues. ${ }^{33}$

In contrast, the regional-local and federal-regional revenue sharing arrangements in Russia are frequently renegotiated. Thus, the revenues of the Russian government at sub-national levels depend on the distribution of bargaining power. As a result of this bargaining, budget funds of local governments are independent of their efforts to raise additional own revenues. Treisman has shown that negotiation over the federal-regional sharing schemes gives regional governments incentives to encourage separatist movements and other forms of political revolt against the federal government. ${ }^{34}$ I focus instead on the effects of fiscal negotiation between local and regional governments. The components of shared revenues at the local level are determined through annual (or bi-annual) negotiations between local and regional officials. ${ }^{35}$ In most regions, the portions of shared taxes and the amounts of transfers are not determined on the basis of a fixed formula, and vary both over time and across localities within a single region.

Regional authorities set target levels of expenditures for localities depending on

\footnotetext{
${ }^{29}$ Table 1, p. 8, in Knight and Li (1999).

${ }^{30}$ Wong (1997, pp. 193-194). In one province, the remittance rate reached up to $87 \%$ for townships. Wong considers this case to be off line with other provinces, however.

${ }^{31}$ Wong (1997, p. 200).

${ }^{32}$ Upper levels of government in China are often not given information about SRF. Also only after 1988, upper levels started to monitor EBF.

${ }^{33}$ See, for instance, Montinola et al. (1995) and Jin et al. (1999).

${ }^{34}$ Treisman (1996a,b, 1997).

${ }^{35}$ Since revenues from shared taxes and transfers are perfect substitutes for both regional and local governments, there is no conceptual difference between shared taxes and transfers.
} 
past experience. These targets serve as a foundation for the amounts of shared revenues to be allocated to each locality. Regional officials estimate the 'needed level of expenditures' for each local government in the region, and the total amount of funds that is to be distributed among the localities in the form of shared taxes and transfers. Regions then negotiate the actual amounts of transfers and shared revenues with localities. As I will show in the empirical section, this system gives local governments of large cities no incentive to maximize city's own revenue because additional local revenues are almost entirely taxed away by the regional authorities.

Therefore, comparison of revenue sharing systems in Chinese and Russian localities may suggest that these systems represent two alternative models of fiscal federalism since local revenues in China depend on the size of the local tax base to a much greater degree than is the case in Russia. ${ }^{36}$

\section{Effects of fiscal incentives, a simple model}

In this section, I consider a very simple model that illustrates how the strength of governmental fiscal incentives can influence local support for business growth and the efficiency of public goods provision.

Consider a mayor of a city, who solves the following maximization problem:

$$
\max _{P, B, S} c P+B+S \quad \text { subject to } P+S \leq S H A R E D+O W N \text {. }
$$

The mayor chooses the level of public goods provision $P$, the level of regulation of private business $B$, and the amount of budget revenues $S$ to be diverted for his private use. ${ }^{37}$ The mayor receives a political benefit from the provision of public goods, given by $c P$. He receives a private benefit from excessive business regulation, given by $B$, as more regulation implies the opportunity to receive more bribes because bribes are offered in exchange for relief from regulations. He also receives private benefit from diverted budgetary revenues, given by $S$. Parameter $c$ is exogenous. I assume that $0<c<1$, i.e. the mayor has higher valuation of private benefits from stealing and bribes compared to political benefits from

\footnotetext{
${ }^{36}$ It is worth noting that in other aspects of political and economic reform, China and Russia either take similar measures, or China has moved more slowly. For example, in such dimensions of reform as the speed of liberalization, the presence of a coherent reform program, the commitment to privatization and to changes in the political system, Russia seems far more advanced. At the same time, both countries still exhibit a lack of the rule of law and insecure private property rights. See Parker et al. (1997).

${ }^{37}$ By regulation I mean registration, licensing and various inspections of firms. Each of these activities is done by a special department of the mayor's office and financed out of the local budget. I assume that budget cost of regulation is independent of the level of regulation, it is mostly wages to inspectors.
} 
spending on public goods. ${ }^{38}$ The level of over-regulation may influence the popularity of the mayor. My assumption is that the private benefit of excessive regulation exceeds its political cost and, therefore, $B$ can be treated as a net benefit of over-regulation to the mayor. ${ }^{39}$

The mayor faces the constraint that the sum of public spending and the amount of diverted funds $P+S$ does not exceed the budget revenues at the mayor's disposal. The budget revenues consist of the sum of shared and own revenues.

Own revenue is an increasing function of the city's tax base which, in turn, depends positively on $P$ and negatively on $B$. Public goods provided by the mayor reduce the costs of business in the city and, therefore, increase entrepreneurial activity. An example of such a public good is law and order. Inefficient overregulation decreases the profitability of business and, therefore, decreases entrepreneurial activity. ${ }^{40}$ By assumption, own revenues consist of a fixed part $\bar{W}$ and a variable part $W(P, B)$ :

$$
O W N=\bar{W}+W(P, B) .
$$

For simplicity, we assume the following form for $W(P, B)$ :

$$
W(P, B)=g(P) y(B),
$$

where $g^{\prime}>0$ and $y^{\prime}<0$.

We assume that shared revenues depend on the amount of own city revenues: they consist of a fixed part $\bar{T}$ and a variable part $T(W)$ that equals $\alpha W$ :

$$
\begin{aligned}
& \text { SHARED }=\bar{T}+T(W) \\
& T(W)=\alpha W .
\end{aligned}
$$

The exogenous parameter $-1 \leq \alpha \leq 0$ represents the weakness of fiscal incentives, i.e. the mayor's ability (or inability) to raise revenues at the margin. If $\alpha=-1$, then fiscal incentives are at their weakest since budget revenues are independent of the mayor's actions, $P, B$, and $S$, because changes in own revenues are fully crowded out by changes in shared revenues. If $\alpha=0$, then a change in the city own tax collections results in an equivalent change in local budget revenues, so fiscal incentives are strong. From the available accounts it appears that $(1+\alpha)$ is most likely significantly greater than zero in China. Empirical investigation in this paper shows that in Russia $(1+\alpha)$ is close to zero.

\footnotetext{
${ }^{38}$ One can treat $1-c$ as cost of effort to provide public goods. An alternative interpretation of $c$ is the mayor's discount factor: the mayor values political benefits because they are a means of getting private benefits in the future.

${ }^{39}$ This assumption is reasonable because otherwise we would not observe any bribes in equilibrium.

${ }^{40}$ For a discussion of these assumptions, see Johnson et al. (1997).
} 
The mayor's optimization problem, therefore, can be rewritten as follows:

$$
\max _{P, B, S} c P+B+S \quad \text { subject to } \quad P+S \leq \bar{T}+\bar{W}+(1+\alpha) g(P) y(B) .
$$

Denote the solution to the mayor's maximization problem to be $S^{*}, P^{*}$, and $B *{ }^{41}$ The following propositions help to illustrate how fiscal incentives affect the decisions of the mayor.

\section{Proposition 1.}

$$
\frac{\mathrm{d} B^{*}}{\mathrm{~d} \alpha}<0, \text { for all } \alpha
$$

\section{Proposition 2.}

$$
\frac{\mathrm{d} P^{*}}{\mathrm{~d} \alpha}>0, \quad \text { for all } \alpha
$$

\section{Proposition 3.}

$$
\left.\frac{\mathrm{d} S^{*}}{\mathrm{~d} \alpha}\right|_{d[\bar{T}+\bar{W}]=-d\left[(1+\alpha) g^{*} y^{*}\right]}<0 .
$$

Propositions 1 and 2 state that as the strength of fiscal incentives rises, level of inefficient regulation decreases and level of public goods provision increases. Fiscal incentives, then, can stimulate entrepreneurial activity and positively influence economic performance. Proposition 3 states that if we compare two cities with equal budget revenues but with different fiscal incentives, the mayor of the city where fiscal incentives are stronger steals less from the city budget. This means that the efficiency of public goods provision is higher in the city with stronger fiscal incentives. An important implication of Propositions 1 and 2 is that city tax base increases with fiscal incentives.

The model does not consider official tax rates explicitly because the effect of

\footnotetext{
${ }^{41}$ For the solution to be unique and determined by F.O.C., I assume that $g(P) y(B)$ is concave with respect to both variables, i.e. $\left(g^{\prime} y^{\prime}\right)^{2}<g y g^{\prime \prime} y^{\prime \prime} ; g^{\prime \prime}(P)<0 ; y^{\prime \prime}(B)<0$.

${ }^{42}$ The proof of Propositions 1-3 is given in Appendix $C$.

${ }^{43}$ Since less revenues are spent on perks and, therefore, more productive public goods are provided using the same amount of budget revenues. By productive public goods I mean public goods that positively influence city tax base.
} 
fiscal incentives on tax rates cannot be tested in the empirical section since there are no data on local tax rates. ${ }^{44}$

This highly stylized model illustrates that the strength of fiscal incentives affects the attitude of politicians towards private businesses and the efficiency of public goods provision.

\section{Data and the empirical methodology}

In this section, I describe the data and specify a number of hypotheses motivated in the previous sections and an empirical strategy to test these hypotheses.

\subsection{Structure and sources of the data}

I use a unique panel data set of cities over a period of 6 years. It contains detailed budgetary data on expenditures, revenue sources and tax shares for shared taxes. This data set includes 35 large cities in 29 regions of Russia for the time period 1992-1997. The data set consists of 29 regional capitals and six other regional centers. The panel is unbalanced, but I have at least 2 years worth of data for each city. Most of the variables come from a questionnaire addressed to the heads of financial and economic departments of city governments. The survey was conducted with substantial help from the League of Russian Cities (LRC) in the summer of 1997. The questionnaire was distributed among 80 local administrations of city-members of the LRC. Responses were received from 49 cities from 34 regions; only 35 cities, however, presented at least 2 years worth of data.

To supplement the LRC survey, data on outcome measures of public goods provision and the number of businesses in the region were provided by Goskomstat. $^{45}$

\subsection{Sample}

The sample used in this paper consists of large, well-developed cities. Each is either the only one or one of a very few 'donor-localities' for their regions. In

\footnotetext{
${ }^{44}$ In generalizations of the model that explicitly include tax rates, the result that the mayor with weaker fiscal incentives regulates more than the mayor with stronger fiscal incentives, still holds. However, the mayor with weak fiscal incentives will have lower tax rates than the mayor with strong fiscal incentives since with weak fiscal incentives the additional taxes do not result in additional budget revenues. Therefore, the overall effect of the strength of fiscal incentives on the local economy is ambiguous: less of distortive taxation should make the tax base grow; more of distortive regulation should make it shrink. If we assume that regulation is sufficiently more distortive than official taxation, then the tax base would increase with fiscal incentives.

${ }^{45}$ Goskomstat is the official Russian statistical agency.
} 
every Russian region, there are usually from one to three city-donors. These are the cities that have more developed economies and, therefore, a larger tax base. These cities are 'net donors' of tax revenues to the consolidated regional budgets. The rest of the localities are 'net recipients' (primarily rural districts that collect very few tax revenues). The tax collections from one donor city can be as much as $70 \%$ of the consolidated revenues of the region. For example, Barnaul, the capital of Altaysky kray and one of its 72 local jurisdictions, contributes $60 \%$ of the consolidated regional tax collections and accounts for less than a third of consolidated regional expenditures. The results of this paper, therefore, are limited only to the relations between regional governments and governments of large cities, and care must be taken in applying the results to smaller cities. ${ }^{46}$ The large cities are where much of official economic activity occurs in Russia; they contribute the most to the growth of the country. ${ }^{47}$

\subsection{Basic facts about the data}

Table 1 presents the composition of expenditures and revenues for an average annual local budget in my sample for 1992-1997. The average annual per capita budget of a large Russian city in 1997 was about $\$ 320 .^{48}$ The largest expenditures have been subsidies to utilities, housing and industrial enterprises, expenditures on education, health care, and social security; in 1997 they constituted 35\%, 23\%, $16 \%$, and $9 \%$ of local expenditures, respectively. Total budget revenues have nearly doubled in real terms over the period, since various expenditure responsibilities have been delegated from the upper levels of government to the localities. The composition of revenues has been changing over time: own revenues have grown from $5 \%$ to $20 \%$ of total revenues. Own revenues, however, had a potential to grow much faster because of increases in the value of property and the growth of markets in these cities. The share of local own revenues in total local revenues is still much smaller in Russia than in most other countries. ${ }^{49}$

Table 1 also exhibits distributions of signs of changes in shared and own

\footnotetext{
${ }^{46}$ There are about 3000 first tier local governments of which 400 are cities. There are about 100 cities comparable in size and political and economic weight in the region to the cities in my sample. The choice of cities in my sample is not random. It depended on the personal ties of the deputy director of the LRC, a former mayor of Kaliningrad, with the mayors of the city-members of LRC. Without these personal ties, it would have been impossible to schedule interviews and convince the city-administrations to fill in the questionnaires. However, I do not have reasons to believe the choice of the cities would systematically affect the findings, except for the fact that these are large city-donors.

${ }^{47}$ Unlike in China, where the rural communities became the location of business growth, rural communities in Russia were practically destroyed by collectivist agriculture.

${ }^{48}$ Russia's GDP per capita in 1997 was $\$ 3092$ (PPP adjusted and corrected for unofficial economy). Total public spending (federal, regional, and local, including off-budget) constituted about $40 \%$ of GDP. Source: Russian Economic Trends (1998).

${ }^{49}$ See footnote 27 for information on size of own revenues in China.
} 
Table 1

Composition of expenditures and revenues of an average city budget, outcomes of public goods provision, changes in shared and own revenues ${ }^{a}$

\begin{tabular}{|c|c|c|c|c|c|c|}
\hline Year & 1992 & 1993 & 1994 & 1995 & 1996 & 1997 \\
\hline $\begin{array}{l}\text { No. of cities with information on current } \\
\text { expenditures and revenues }\end{array}$ & 24 & 25 & 29 & 31 & 35 & 41 \\
\hline $\begin{array}{l}\text { Average population of the cities } \\
\text { (people, thousand) }\end{array}$ & 619 & 610 & 576 & 571 & 536 & 510 \\
\hline Expenditures (total, 1997 R billion): & 533 & 662 & 724 & 782 & 937 & 953 \\
\hline $\begin{array}{l}\text { (1) Subsidies to utilities, housing } \\
\text { and enterprises }(\%)\end{array}$ & 28.4 & 30.5 & 35.6 & 36.1 & 34.6 & 34.5 \\
\hline (2) Education (\%) & 19.4 & 19.4 & 21.7 & 22.2 & 22.9 & 22.9 \\
\hline (3) Health care (\%) & 19.3 & 18.6 & 19.9 & 17.2 & 16.0 & 16.2 \\
\hline (4) Social security (\%) & 4.8 & 2.4 & 4.2 & 6.2 & 8.0 & 8.6 \\
\hline (5) Administration (\%) & 1.6 & 1.9 & 2.4 & 2.3 & 2.5 & 2.7 \\
\hline (6) Culture and sports (\%) & 0.6 & 0.7 & 1.2 & 1.5 & 1.2 & 1.1 \\
\hline (7) Other $(\%)$ & 25.9 & 26.5 & 15.0 & 14.5 & 14.8 & 14.0 \\
\hline Revenues (total, 1997 R billion): & 569 & 684 & 788 & 837 & 941 & 953 \\
\hline (i) Shared revenues $(\%)$ & 94.8 & 89.5 & 85.6 & 81.8 & 83.2 & 80.1 \\
\hline (1) Federal and regional taxes $(\%)$ & 86.9 & 79.5 & 77.3 & 73.4 & 65.6 & 61.4 \\
\hline (2) Transfers from the regions $(\%)$ & 7.9 & 10.0 & 8.3 & 8.4 & 17.6 & 18.7 \\
\hline (ii) Own revenues $(\%)$ & 5.2 & 10.5 & 14.4 & 18.2 & 16.5 & 19.9 \\
\hline (1) Local taxes (\%) & 0.6 & 6.9 & 11.6 & 14.7 & 14.0 & 17.2 \\
\hline (2) Non-tax revenues $(\%)$ & 4.6 & 3.6 & 2.8 & 3.5 & 2.5 & 2.7 \\
\hline $\begin{array}{l}\text { No. of cities with non-missing data on } \\
\Delta_{t} \text { in shared and own revenues }\end{array}$ & & 24 & 25 & 29 & 31 & 31 \\
\hline $\begin{array}{l}\text { No. of cities with the same sign of } \\
\Delta_{t} \text { in own and shared revenues }\end{array}$ & & 18 & 16 & 15 & 18 & 12 \\
\hline $\begin{array}{l}\text { No. of cities with opposite signs of } \\
\Delta_{t} \text { in own and shared revenues }\end{array}$ & & 6 & 9 & 14 & 13 & 19 \\
\hline $\begin{array}{l}\text { Change in own revenues } \\
\text { (average } \Delta_{t}, 1997 \mathrm{R} \text { billion) }\end{array}$ & & 84.7 & 76.8 & -10.8 & 12.9 & 39.5 \\
\hline $\begin{array}{l}\text { Change in shared revenues } \\
\text { (average } \Delta_{t}, 1997 \mathrm{R} \text { billion) }\end{array}$ & & 44.5 & 33.3 & 38.2 & 21.7 & 56.5 \\
\hline $\begin{array}{l}\text { Infant mortality } \\
\text { (no. died per thousand born) }\end{array}$ & 17.9 & 19.5 & 18.1 & 18.4 & 18.0 & 18.5 \\
\hline $\begin{array}{l}\text { Children attending schools in } \\
\text { the evening ( } \% \text { to total) }\end{array}$ & 32.6 & 33.9 & 31.2 & 30.1 & 28.7 & 30.7 \\
\hline $\begin{array}{l}\text { New business formation } \\
\text { (no. of firms, thousand) }\end{array}$ & & 5.3 & 5.9 & -1.2 & -1.6 & -1.1 \\
\hline
\end{tabular}

\footnotetext{
${ }^{a}$ Nominal variables in 1997 constant prices. Average dollar exchange rate for 1997 is 5600 rubles per dollar. 1997 data planned not actual. Federal taxes include profit tax, VAT, personal income tax, and excise tax; regional taxes include property taxes, natural resources payments, trade taxes, and other regional taxes; non-tax revenues include privatization proceeds, revenues from municipal property leases, and other non-tax revenues.
} 
revenues over time and yearly averages of the measures of public goods provision. $^{50}$ A more complete set of descriptive statistics for all variables is presented in Appendix B.

\subsection{Empirical methodology}

Hypothesis I. In Russia, local fiscal incentives are very weak on average ( $\alpha$ from the model above is close to minus one). Regional administrations cut transfers to local governments and lower the local portion of shared taxes when the city collects more on its own.

The alternative hypothesis is that local governments have strong fiscal incentives. At the extreme, the alternative implies that shared revenues are determined independently of shifts in own revenues. The alternative hypothesis is closer to the description of Chinese federalism given in the 'market-preserving federalism' literature. Jin et al. report that at the province-level in 1982-1992 in China, $\alpha$ is about -0.16 on average. To test this hypothesis, I estimate the following equation:

$$
\begin{aligned}
\Delta\left[\begin{array}{l}
\text { shared } \\
\text { revenues }
\end{array}\right]_{i t}= & \alpha \Delta\left[\begin{array}{l}
\text { own } \\
\text { revenues }
\end{array}\right]_{i t}+\eta\left[\begin{array}{l}
\text { popu- } \\
\text { lation }
\end{array}\right]_{i t}+\left[\begin{array}{l}
\text { city } \\
\text { effect }
\end{array}\right]_{i} \\
& +\gamma^{\prime}\left[\begin{array}{l}
\text { year } \\
\text { dummy }
\end{array}\right]_{t}+\varepsilon_{i t}
\end{aligned}
$$

$H_{\mathrm{O}}: \alpha=-1 ; H_{\mathrm{a}}: \alpha$ is close to 0 .

In Eq. (7), both shared and own revenues are measured in constant rubles; $\Delta$ denotes annual changes; $i$ is the city subscript; $t$ is the year subscript; and $\varepsilon_{i t}$ is an error term. Given that there is no intercept in the regression and the sum of city effects is constrained to zero, the parameter $\alpha$ represents the crowding out of own revenues by shared revenues from Eq. (5) in the model. For a one-ruble increase in own revenues, shared revenues, on average, decrease by $\alpha$ rubles. The closer is $\alpha$ to minus one, the weaker the fiscal incentives. The closer it is to zero, the stronger the fiscal incentives.

For the shared and own revenues, I use the following definitions. Shared revenues are equal to the sum of the actual local budgetary revenues from federal and regional shared taxes, and the actual transfer from the budget of the region. ${ }^{51}$ Own revenues are equal to the sum of local taxes and local non-tax revenues. Panel data allow me to make use of variation both across cities and over time. ${ }^{52}$

\footnotetext{
${ }^{50}$ Precise definitions of the variables are given in the methodology section.

${ }^{51}$ Details on construction of these variables are given in Table 1.

${ }^{52}$ This is particularly important because of the small sample size of 139 observations in first differences.
} 
For estimation of Eq. (7) and for all other estimation procedures in this paper (unless stated otherwise), specifications with fixed and random city-specific effects are used. City-specific effects in the regressions control for unobservable cityspecific, time-invariant differences across cities that may affect the dependent variables. There are many such variables, ranging from geography to special federal projects. I also include year dummies in the regressions to control for systematic changes in the shared revenues of all cities in a particular year. Examples of these systematic changes are the mandatory transfers of expenditures from the federal and regional level to the local level of government initiated by federal laws, such as an increase in childcare benefits or veteran pensions. Population is used in specification (7) to control for the fact that the relation between the shared and own revenues may depend on the size of the city. I also report the result of simple OLS regression of changes in shared revenues on changes in own revenues with no constant term and no controls. Eq. (7) is estimated both using the whole sample and on a sub-sample that excludes planned data for 1997.

Hypothesis II. The speed of private business formation in a city is positively correlated with the local government's fiscal incentives.

Hypothesis II is hard to test directly because data on business formation at the city-level are unavailable. I consequently use region-level data. The results of the test using the following specifications are merely suggestive.

$$
\begin{aligned}
\Delta\left[\begin{array}{l}
\text { number of } \\
\text { businesses }
\end{array}\right]_{i t}= & \theta\left[\begin{array}{l}
\text { incentives } \\
\text { proxy }
\end{array}\right]_{i t}+\lambda\left[\begin{array}{l}
\text { popu- } \\
\text { lation }
\end{array}\right]_{i t} \\
& +\chi\left[\ln \left(\begin{array}{l}
\text { total expend. } \\
\text { per capita }
\end{array}\right)\right]_{i t}+\left[\begin{array}{l}
\text { city } \\
\text { effect }
\end{array}\right]_{i}+\gamma^{\prime}\left[\begin{array}{l}
\text { year } \\
\text { dummy }
\end{array}\right]_{t} \\
& +\varepsilon_{i t}
\end{aligned}
$$

$H_{\mathrm{O}}: \theta>0 ; H_{\mathrm{a}}: \theta \leq 0$.

In Eq. (8), incentives proxy is a variable that measures the strength of fiscal incentives of the city government in city $i$ in year $t$. I use a very simple proxy for fiscal incentives: it is equal to zero if changes in shared and own revenues have opposite signs; otherwise, the incentives proxy is equal to one. An incentives proxy equal to zero is an indicator of weaker fiscal incentives and an incentives proxy equal to one is an indicator of stronger fiscal incentives. Tax bases for shared and local taxes in a city are highly positively correlated, both being functions of the level of economic development in this city. ${ }^{53}$ So, if shared and own revenues shift in different directions (i.e. the incentives proxy equals zero),

\footnotetext{
${ }^{53}$ Correlation coefficient between tax base for shared taxes and local own revenues is 0.58 , significant at the $1 \%$ level.
} 
then there is some crowding-out of changes in own revenues by changes in shared revenues and the local government is not financially independent from the regional government. One should note that positive incentives proxy does not necessarily mean that there is no such crowding-out. For example, during the transition period, regional governments have been transferring some functions to the local level along with shared revenues that were supposed to pay for these mandatory changes in expenditure responsibilities. This process made it harder to identify the extent of fiscal crowding-out. ${ }^{54}$ In short, the measure of the strength of fiscal incentives suggested here is quite noisy.

The variable $\Delta$ (number of businesses) is the number of newly privatized and newly opened businesses in the region. ${ }^{56}$ Given the assumption that most registered economic activity is going on in the large cities, this variable captures the variation in business formation within the regional capital cities.

As noted, population is included in the regression to control for city-size. Naturally, under otherwise similar conditions, fewer businesses can be formed in the smaller cities. The log of budgetary expenditures per capita is an important control for the need to increase the local tax base: the lower the expenditures per capita, the higher the need for additional own revenues ceteris paribus assuming that they will not be taxed away by the regional authorities. It is worth noting that while this control is endogenous to the number of businesses in a city, it is exogenous to its first difference since for the sample period newly emerging businesses were granted tax holidays for the first year of their existence. ${ }^{57}$

\footnotetext{
${ }^{54}$ If both changes in shared revenues and in own revenues are positive, it could reflect the fact that the regional government transferred some functions to the local level with funds sufficient to cover only part of these expenditures. This example shows that there could still be some crowding out even when changes in shared and own revenues are both positive. Most of the mandatory transfers of functions were ordered by federal (and not regional) legislation, however, and should affect all cities at the same time. In that case, year dummies take care of this mis-measurement problem.

${ }^{55}$ There are three alternative measures of fiscal incentives that I have tried to use. One is to take the residuals from the regression (1). Positive values of residuals then indicate above average fiscal incentives and negative values of residuals indicate below average fiscal incentives. This approach gives qualitative results that are similar to the results reported in this paper. Statistically, however, these results are rarely significant. This is probably because continuous variables that would measure the strength of financial incentives suffers from the problem of unobserved mandatory expenditures just as the binary measure but the continuous variable is noisier. Another approach is to estimate fiscal incentives for each city using time series data. This approach yields similar qualitative results to ones reported in the paper, however, the results are statistically insignificant due to a small sample problem in the time series component of the data. The third approach is to use a binomial indicator of fiscal incentives just as in the paper but other cut-off points in splitting the sample in two groups with better and worse fiscal incentives. I have tried several reasonable cut-off points and they yield practically the same results as the ones reported in the paper.

${ }^{56}$ This variable is not adjusted to exclude from consideration those new businesses that arise from the splitting-up of existing firms.

${ }^{57}$ Corporate income tax law of Russian Federation. The law was adopted on 12/27/91. Tax holidays remained in the law up until 1998.
} 
Hypothesis III. If fiscal incentives are strong, then public goods are provided more efficiently than when fiscal incentives are weak.

Two approaches to testing this hypothesis are employed. Firstly, for a given level of expenditures on a certain public good, the strength of fiscal incentives should affect outcome of provision of this public good since a smaller portion of funds is wasted or stolen. I estimate the following equation using the whole sample to test this:

$$
\begin{aligned}
{\left[\begin{array}{l}
\text { outcome of public } \\
\text { goods provision }
\end{array}\right]_{i t}=} & \delta\left[\begin{array}{l}
\text { incentives } \\
\text { proxy }
\end{array}\right]_{i t}+\omega\left[\ln \left(\begin{array}{l}
\text { public expend. } \\
\text { per capita }
\end{array}\right)\right] \\
& +\kappa\left[\begin{array}{l}
\text { popu- } \\
\text { lation }
\end{array}\right]_{i t}+\left[\begin{array}{l}
\text { city } \\
\text { effect }
\end{array}\right]_{i}+\gamma^{\prime}\left[\begin{array}{l}
\text { year } \\
\text { dummy }
\end{array}\right]_{t}+\varepsilon_{i t}
\end{aligned}
$$

$H_{\mathrm{O}}: \delta>0 ; H_{\mathrm{a}}: \delta \leq 0$.

I use two measures of outcomes associated with public goods provision: the infant mortality rate and the share of school children who must attend school in the evening due to overcrowded schools. These measures were chosen because they seem likely to depend on the quality of public goods provision, and they are directly related to government choices over which data are available. Health literature establishes that the availability of primary care in the first days of life is, on the one hand, a direct function of outlays on primary care and, on the other hand, an important determinant of infant mortality. In addition, the availability of schools in Russia is also very closely dependent on current local government expenditures. There is a paradoxical situation: the number of schools per child is very high in Russia relative to most developed countries, but the percentage of students who attend schools in the evening due to overcrowded schools is also very high. This is because many existing schools, a legacy of soviet welfare state, are currently closed. To open these schools, local governments need to make (unsubstantial but necessary) renovations financed by capital outlays from the local budgets. In estimation of Eq. (9), I consider health care and education expenditures as public expenditures corresponding to the outcomes of public goods provision described above.

Three different specifications were used to estimate Eq. (9): fixed effects, random effects, and fixed effects with an instrument for public expenditures per capita. One might suspect that expenditures per capita are correlated with some component of the error term $\varepsilon$, in which case the fixed and random effects specifications yield biased and inconsistent estimates of the parameters. ${ }^{58}$ So, I

\footnotetext{
${ }^{58}$ For instance, it may be the case that infant mortality is low in the richer cities because of better nutrition and, in these cities, public expenditures are also large because of high tax revenues. In this case, a consistent and unbiased estimate of the effect of the incentives proxy on measures of public goods provision, given the level of expenditures, can be obtained by using instrumental variables. I also present a robustness check in Section 6 that controls for this possible endogeneity problem. It repeats the analysis on a sub-sample that excludes richer cities.
} 
instrument budgetary expenditures on education and health care of the city with the regional ratio of industrial to agricultural output. ${ }^{59}$ The choice of specification does not substantially affect the results, however.

An alternative, perhaps, more convincing way to test Hypothesis III would be to look at the interaction between the incentives proxy and expenditures per capita. Due to the simple nature of the incentives proxy, the approach to test Hypothesis III is to divide the data into two sub-samples, based on whether incentives proxy is equal to one or zero..$^{60}$ Then, I run separate regressions on each sub-sample, regressing outcome measures on the logarithm of corresponding public expenditures, and the population, with city-specific random effects. This approach gets around a possible problem of reverse causality in Eq. (9): if the regional governments bail out only the localities where outcomes of public goods provision are low and do not bail out localities with high outcomes of public goods provision then one could get a positive effect of the incentives proxy in Eq. (9) even if the efficiency of provision is the same across localities. Estimation of Eq. (10) directly tests the impact of expenditures on outcomes

$$
\begin{aligned}
{\left[\begin{array}{l}
\text { outcome of public } \\
\text { goods provision }
\end{array}\right]_{i t}=} & \rho\left[\ln \left(\begin{array}{l}
\text { public expend. } \\
\text { per capita }
\end{array}\right)\right]_{i t}+\kappa\left[\begin{array}{l}
\text { popu- } \\
\text { lation }
\end{array}\right]_{i t} \\
& +\left[\begin{array}{l}
\text { city } \\
\text { effect }
\end{array}\right]_{i}+\gamma^{\prime}\left[\begin{array}{l}
\text { year } \\
\text { dummy }
\end{array}\right]_{t}+\varepsilon_{i t} .
\end{aligned}
$$

Hypothesis III implies that $\rho$ will be greater in magnitude and more significant for the sub-sample with better fiscal incentives (the sub-sample where the incentives proxy equals one).

In Section 6, I present the results of a robustness check against an alternative explanation that is consistent with Hypotheses II and III. The methodology of this check is based on testing the described hypotheses on a sub-sample that excludes observations with shared and own revenues increasing simultaneously.

\subsection{Correlations}

Before the presentation of formal regression results, I report some basic correlations between the variables used for the regression analysis. Table 2 presents these correlations.

Annual changes in shared and own revenues are negatively correlated with a correlation coefficient of -0.44 significant at the $1 \%$ level. Incentives proxy is

\footnotetext{
${ }^{59}$ Shares of industrial and agricultural production in total output are argued to be a legacy of the soviet planning system and, therefore, can be viewed as exogenous.

${ }^{60}$ The incentives variable is highly correlated with the interaction term: the correlation coefficient is 0.9999. So, the effect of interaction term on outcomes of public goods provision is statistically indistinguishable from the effect of the incentives proxy.
} 
Table 2

Pair-wise correlation coefficients

\begin{tabular}{llrl}
\hline Change in own revenues & Change in shared revenues & $-0.44^{\mathrm{a}}$ & $(0.00)$ \\
Population & Incentives proxy & -0.07 & $(0.44)$ \\
Total budgetary revenues & Incentives proxy & -0.03 & $(0.65)$ \\
Total expenditures per capita & Incentives proxy & -0.02 & $(0.84)$ \\
New business formation & Incentives proxy & 0.15 & $(0.12)$ \\
Infant mortality & Incentives proxy & $-0.16^{\mathrm{c}}$ & $(0.06)$ \\
Unavailability of schools & Incentives proxy & -0.07 & $(0.40)$ \\
Infant mortality & Health care expenditures per capita & $-0.25^{\mathrm{a}}$ & $(0.00)$ \\
Unavailability of schools & Education expenditures per capita & $-0.16^{\mathrm{a}}$ & $(0.04)$ \\
\hline
\end{tabular}

${ }^{\mathrm{a} a}{ }^{\mathrm{a}} \mathrm{b}$ and ${ }^{\mathrm{c}}$ denote significance at 1,5 and $10 \%$ levels, respectively. $P$-values in parentheses.

positively correlated with the new business formation variable (insignificant) and outcomes of public goods provision: infant mortality (correlation coefficient is equal to -0.16 significant at $0.7 \%$ ) and unavailability of schools (coefficient equals -0.07 insignificant). Incentives proxy is also slightly negatively correlated with the size of the city (insignificant). The signs of all these correlations are as implied by Hypotheses I-III.

Health care expenditures per capita are negatively correlated with infant mortality, while education expenditures per capita are negatively correlated with unavailability of schools. This provides evidence that these outcomes of public goods provision are indeed related to local government policies.

\section{Empirical evidence from Russian cities}

In this section, I present evidence that the fiscal incentives of Russian local governments are very weak; I show, further, that the absence of fiscal incentives has a deleterious effect on the business formation and the efficiency of public goods provision.

Table 3 presents the effect of changes in own revenues on changes in shared revenues in the local budgets. The main finding is that when own revenues of the city budget rise, they are on average almost entirely offset by a decrease in the shared revenues in the city budget, just as Hypothesis I postulates. The coefficient of change in own revenues, $\alpha$, is below -0.9 (with a standard error of 0.14 ) and is stable across specifications. ${ }^{61}$ The $95 \%$ confidence interval for the coefficient of change in own revenues is $[-1.20 ;-0.67]$. This is a very large crowding-out rate, statistically indistinguishable from complete crowding-out. This result is in-

\footnotetext{
${ }^{61}$ There is no intercept in the regressions of Table 3. The main result is independent of whether the sum of city effects is constrained to zero or not. Both approaches lead to the same coefficient of the change in own revenues up to a third decimal with almost the same significance level. This is because the sum of the city effects (when unconstrained) is not significantly different from zero.
} 
Table 3

Changes in own revenues are crowded out by changes in shared revenues

\begin{tabular}{|c|c|c|c|c|c|c|}
\hline \multirow{4}{*}{$\begin{array}{l}\text { Dependent variable } \\
\text { Sample } \\
\text { Specification }\end{array}$} & \multicolumn{6}{|c|}{ Change in shared revenues } \\
\hline & \multicolumn{4}{|l|}{ Whole sample } & \multicolumn{2}{|l|}{ Excluding 1997} \\
\hline & (1) & (2) & (3) & (4) & (5) & (6) \\
\hline & Fixed effects & Fixed effects & $\begin{array}{l}\text { Random } \\
\text { effects, OLS }\end{array}$ & OLS & Random effects & OLS \\
\hline Change in own revenues & $\begin{array}{l}-0.905^{\mathrm{b}} \\
(-6.28)\end{array}$ & $\begin{array}{l}-0.906^{\mathrm{b}} \\
(-6.31)\end{array}$ & $\begin{array}{l}-0.940^{\mathrm{b}} \\
(-7.08)\end{array}$ & $\begin{array}{l}-0.79^{b} \\
(-5.66)\end{array}$ & $\begin{array}{l}-0.99^{\mathrm{b}} \\
(-5.82)\end{array}$ & $\begin{array}{l}-0.80^{\mathrm{b}} \\
(-4.51)\end{array}$ \\
\hline Population & $\begin{array}{c}-545.39 \\
(-0.48)\end{array}$ & & $\begin{array}{r}181.30^{\mathrm{b}} \\
(4.79)\end{array}$ & & $\begin{array}{r}173.45^{\mathrm{b}} \\
(4.16)\end{array}$ & \\
\hline No. of cities & 35 & 35 & 35 & 35 & 31 & 31 \\
\hline Sample size & 139 & 139 & 139 & 139 & 109 & 109 \\
\hline$R^{2}$ within & 0.33 & 0.32 & 0.32 & & 0.36 & \\
\hline$R^{2}$ between & 0.07 & 0.05 & 0.38 & & 0.11 & \\
\hline$R^{2}$ overall & 0.10 & 0.22 & 0.34 & 0.19 & 0.32 & 0.7 \\
\hline Hausman test: $\chi^{2}(k)$ & & & 1.91 & & 4.54 & \\
\hline Hausman test: $\operatorname{Pr}>x^{2}$ & & & 0.93 & & 0.47 & \\
\hline
\end{tabular}

${ }^{a}$ Revenues in constant rubles. (1)-(3) and (5) include year dummies. $T$-statistics in parentheses.

${ }^{\mathrm{b}}$ Denotes significance at $1 \%$ level. In (3), results of the OLS regression and random effects regression are identical since estimated variance of random effects is zero. $k$ in Hausman test is equal to 6 in (3) and 5 in (5). 
dependent of whether the regression is run on the whole sample or a sub-sample excluding observations from 1997 based on planned data. The coefficient $\alpha$ has a direct interpretation: 90 kopecks out of each additional ruble in own revenues is taxed away by the regional government through decreased tax shares and transfers. A crowding-out rate this large gives local government no incentives to encourage the growth of private business in order to boost own tax revenues because local governments in Russia simply cannot raise revenues at the margin. ${ }^{62}$

Table 3 provides evidence that budget constraints for local governments are soft, since regional governments not only tax away marginal own revenues, but also provide additional revenues if there is a shortfall in own revenues.

This result could be compared with the argument presented by Oi (1992), Montinola et al. (1995), Qian and Weingast (1996), and Jin et al. (1999); in China, changes in local shared revenues in many localities are independent of the changes in local own (off-budget) revenues since within-budget revenues are shared according to predetermined contracts and, therefore, parameter $\alpha$ is closer to zero in these localities. As has been already noted, however, there are some prosperous townships where all within-budget revenues are shared and shares are negotiated annually. ${ }^{63}$ The opposite to the main conclusion of 'market-preserving federalism' literature is true in Russia: the result in Table 3 shows that Russian localities do not have a secure, independent source of revenue that would not be subject to seizure by the regional governments. Local governments in Russia never became independent fiscal entities. There is quite a lot of evidence that Russian local governments over-regulate business, whereas Chinese local governments make efforts to promote entrepreneurial activity in their communities. Abstracting from other constitutional and political differences between China and Russia (that, in my opinion, are likely to make differences in performance of local governments of two countries smaller rather than larger), one could suggest that incentives created by different systems of revenue sharing may potentially, indeed, have impact on local governments policies to create a favorable business environment.

One has to note that extra-budgetary funds exist in Russia as well as in China. However, one must distinguish Chinese and Russian extra-budgetary funds. Extra-budgetary funds, while quite large on the regional and federal level in Russia, generally either do not exist or are very small at the local level. I collected this information from interviews with mayors in several Russian cities, and it is supported by data on extra-budgetary funds available for a few cities. Most cities in my sample do not have extra-budgetary funds at all. This data, however, could

\footnotetext{
${ }^{62}$ The results of Table 3 could be generated if there just is a certain total amount of taxes that can be collected from each territory, in other words, if for some exogenous reason tax bases for shared and own taxes are almost perfectly negatively correlated. The tax bases for shared and own taxes, however, are positively correlated both in across cities and over time. Correlation coefficient is 0.58 , significant at $1 \%$ level.

${ }^{63}$ See Wong (1997, p. 194).
} 
mean only that the mayors are reluctant to give information about these extrabudgetary funds. But the mayors have argued that there are no stable sources of revenues for the extra-budgetary funds on the local level (even when the funds exist) since all stable sources of revenues are tied to within-budget own-revenues of the local governments. In short, Russian extra-budgetary funds at the local level are unlikely to undermine the results of Table 3 .

The results also suggest an explanation for the puzzle of why private businesses in Moscow and St. Petersburg have grown much faster than businesses in other large Russian cities. Both of Russia's capitals have the status of regional governments and may thus have fewer problems with fiscal incentives.

Table 4 presents evidence in support of Hypothesis II. The strength of fiscal incentives in cities is positively related (significant at the $10 \%$ level) to the number of newly formed businesses in the region. This is only a very weak test, since one has to assume that formation of private business in the region is highly correlated with formation of private business in its capital city. If this assumption is to be believed, the number of newly opened or privatized businesses in the group with better incentives is 1710 higher (or $18 \%$ of the mean number of registered businesses in the sample) than in the group with worse fiscal incentives.

As discussed in Section 3, weak fiscal incentives have implications for how efficiently public money is spent at the local level. Tables 5 and 6 evaluate this proposition. Table 5 presents the results of the estimation of Eq. (9). The measures of the outcomes of public goods provision are positively affected by the strength

Table 4

New business formation as a function of government incentives

\begin{tabular}{|c|c|c|c|}
\hline \multirow[t]{2}{*}{ Dependent variable } & \multicolumn{3}{|c|}{$\begin{array}{l}\text { No. of created this year private de novo and privatized } \\
\text { firms }\end{array}$} \\
\hline & (1) & $(2)$ & (3) \\
\hline Specification & Fixed effects & Random effects & OLS \\
\hline Incentives proxy & $\begin{array}{r}1.71^{\mathrm{c}} \\
(1.91)\end{array}$ & $\begin{array}{r}1.46^{\mathrm{c}} \\
(1.83)\end{array}$ & $\begin{array}{c}1.31 \\
(1.54)\end{array}$ \\
\hline Population & $\begin{array}{r}0.007 \\
(0.25)\end{array}$ & $\begin{array}{r}0.001 \\
(1.29)\end{array}$ & \\
\hline Log of expenditures per capita & $\begin{array}{l}-9.22^{\mathrm{a}} \\
(-4.41)\end{array}$ & $\begin{array}{l}-5.46^{\mathrm{a}} \\
(-4.09)\end{array}$ & \\
\hline Constant & & & $\begin{array}{c}0.35 \\
(0.62)\end{array}$ \\
\hline No. of cities & 27 & 27 & 27 \\
\hline Sample size & 112 & 112 & 112 \\
\hline$R^{2}$ within & 0.23 & 0.22 & \\
\hline$R^{2}$ between & 0.22 & 0.27 & \\
\hline$R^{2}$ overall & 0.11 & 0.15 & 0.02 \\
\hline
\end{tabular}

${ }^{\mathrm{a}}$ Incentives proxy $=1$ if annual changes in shared and own revenues have the same sign, and $=0$ otherwise. (1) and (2) include year dummies. $T$-statistics in parentheses. ${ }^{\mathrm{a}}$ and ${ }^{\mathrm{c}}$ denote significance at 1 and $10 \%$ levels, respectively. Hausman test for $(2): \chi^{2}(2)=7.04 ; \operatorname{Pr}>\chi^{2}=0.07$. 
Table 5

Efficiency of public goods provision is a function of government incentives

\begin{tabular}{|c|c|c|c|c|c|c|c|c|}
\hline \multirow[t]{2}{*}{ Dependent variable } & \multicolumn{4}{|c|}{ Infant mortality } & \multicolumn{4}{|c|}{ Unavailability of schools } \\
\hline & (1) & (2) & (3) & (4) & (5) & (6) & (7) & (8) \\
\hline Specification & $\begin{array}{l}\text { Fixed } \\
\text { effects }\end{array}$ & $\begin{array}{l}\text { Random } \\
\text { effects }\end{array}$ & OLS & $\begin{array}{l}\text { IV, Fixed } \\
\text { effects }\end{array}$ & $\begin{array}{l}\text { Fixed } \\
\text { effects }\end{array}$ & $\begin{array}{l}\text { Random } \\
\text { effects }\end{array}$ & OLS & $\begin{array}{l}\text { IV, Fixed } \\
\text { effects }\end{array}$ \\
\hline Incentives proxy & $\begin{array}{l}-0.97^{\mathrm{b}} \\
(-2.57)\end{array}$ & $\begin{array}{l}-0.99^{\mathrm{a}} \\
(-2.70)\end{array}$ & $\begin{array}{l}-1.35^{\mathrm{c}} \\
(-1.83)\end{array}$ & $\begin{array}{l}-0.99^{\mathrm{b}} \\
(-2.35)\end{array}$ & $\begin{array}{l}-1.60^{\mathrm{b}} \\
(-2.53)\end{array}$ & $\begin{array}{l}-1.71^{\mathrm{a}} \\
(-2.71)\end{array}$ & $\begin{array}{l}-0.60 \\
(-0.76)\end{array}$ & $\begin{array}{l}-1.48^{\mathrm{c}} \\
(-1.82)\end{array}$ \\
\hline $\begin{array}{l}\text { Log of health care expend. } \\
\text { per capita }\end{array}$ & $\begin{array}{c}0.25 \\
(-0.41)\end{array}$ & $\begin{array}{c}0.35 \\
(-0.58)\end{array}$ & & $\begin{array}{l}0.43 \\
(0.215)\end{array}$ & & & & \\
\hline $\begin{array}{l}\text { Log of education expend. } \\
\text { per capita }\end{array}$ & & & & & $\begin{array}{l}-0.22 \\
(-0.14)\end{array}$ & $\begin{array}{r}-0.06 \\
(0.05)\end{array}$ & & $\begin{array}{l}-2.78^{\mathrm{a}} \\
(-3.78)\end{array}$ \\
\hline Population & $\begin{array}{c}0.01 \\
(0.85)\end{array}$ & $\begin{array}{l}-0.00 \\
(-0.01)\end{array}$ & & $\begin{array}{c}0.01 \\
(1.21)\end{array}$ & $\begin{array}{l}-0.02 \\
(-0.79)\end{array}$ & & & $\begin{array}{l}-0.02 \\
(-0.91)\end{array}$ \\
\hline Constant & & & $\begin{array}{l}19.25^{\mathrm{a}} \\
(34.5)\end{array}$ & & & & $\begin{array}{l}31.11^{\mathrm{a}} \\
(51.5)\end{array}$ & \\
\hline No. of cities & 35 & 35 & 35 & 35 & 35 & 35 & 35 & 35 \\
\hline Sample size & 138 & 138 & 139 & 135 & 139 & 139 & & 135 \\
\hline$R^{2}$ within & 0.16 & 0.16 & & & 0.36 & 0.35 & & \\
\hline$R^{2}$ between & 0.00 & 0.06 & & & 0.00 & 0.01 & & \\
\hline$R^{2}$ overall & 0.01 & 0.05 & 0.03 & 0.05 & 0.02 & 0.13 & & 0.10 \\
\hline Hausman test: $\chi^{2}(7)$ & & 3.30 & & & & 2.50 & & \\
\hline Hausman test: $\operatorname{Pr}>\chi^{2}$ & & 0.86 & & & & 0.87 & & \\
\hline
\end{tabular}

${ }^{a}$ Unavailability of schools measured by percent of children who attend school in the evening. Incentives proxy $=1$ if annual changes in shared and own revenues have the same sign, and $=0$ otherwise. (1), (2), (5), and (6) include year dummies. (4) and (8) use ratio of industrial to agricultural output in the region to instrument for $\log$ expenditures per capita in the city. $T$-statistics are in parentheses. ${ }^{\mathrm{a}, \mathrm{b}}$ and ${ }^{\mathrm{c}}$ denote significance at 1,5 and $10 \%$ levels, respectively. 
Table 6

Efficiency of expenditures is a function of government incentives: separate estimations on sub-samples with better and worse fiscal incentives

\begin{tabular}{|c|c|c|c|c|c|c|c|c|c|c|c|c|}
\hline \multirow{3}{*}{$\begin{array}{l}\text { Dependent variable } \\
\text { Specification } \\
\text { Value of incentives proxy }\end{array}$} & \multicolumn{6}{|c|}{ Infant mortality } & \multicolumn{6}{|c|}{ Unavailability of schools } \\
\hline & \multicolumn{2}{|c|}{$\begin{array}{l}\text { (1) } \\
\text { Fixed effects }\end{array}$} & \multicolumn{2}{|c|}{$\begin{array}{l}\text { (2) } \\
\text { Random effects }\end{array}$} & \multicolumn{2}{|l|}{$\begin{array}{l}\text { (3) } \\
\text { OLS }\end{array}$} & \multicolumn{2}{|c|}{$\begin{array}{l}\text { (4) } \\
\text { Fixed effects }\end{array}$} & \multicolumn{2}{|c|}{$\begin{array}{l}\text { (5) } \\
\text { Random effects }\end{array}$} & \multicolumn{2}{|l|}{$\begin{array}{l}(6) \\
\text { OLS }\end{array}$} \\
\hline & 1 & 0 & 1 & 0 & 1 & 0 & 1 & 0 & 1 & 0 & 1 & 0 \\
\hline $\begin{array}{l}\text { Log of health care exp. } \\
\text { per capita }\end{array}$ & $\begin{array}{l}-2.50^{\mathrm{c}} \\
(-1.85)\end{array}$ & $\begin{array}{l}0.17 \\
(0.31)\end{array}$ & $\begin{array}{l}-4.00^{\mathrm{a}} \\
(-3.35)\end{array}$ & $\begin{array}{c}0.24 \\
(0.47)\end{array}$ & $\begin{array}{l}-5.29^{\mathrm{a}} \\
(-4.20)\end{array}$ & $\begin{array}{l}-0.69 \\
(-0.52)\end{array}$ & & & & & & \\
\hline $\begin{array}{l}\text { Log of education exp. } \\
\text { per capita }\end{array}$ & & & & & & & $\begin{array}{l}-8.98^{\mathrm{a}} \\
(-4.11)\end{array}$ & $\begin{array}{l}-1.12 \\
(-0.68)\end{array}$ & $\begin{array}{l}-6.56^{\mathrm{a}} \\
(-4.20)\end{array}$ & $\begin{array}{l}-0.14 \\
(-0.11)\end{array}$ & $\begin{array}{l}-5.31^{\mathrm{a}} \\
(-3.36)\end{array}$ & $\begin{array}{r}1.31 \\
(0.83)\end{array}$ \\
\hline Population & $\begin{array}{c}0.03 \\
(1.17)\end{array}$ & $\begin{array}{l}-0.00 \\
(-0.06)\end{array}$ & $\begin{array}{c}-0.00 \\
(0.65)\end{array}$ & $\begin{array}{c}-0.00 \\
(-0.91)\end{array}$ & & & $\begin{array}{c}0.01 \\
(0.38)\end{array}$ & $\begin{array}{l}-0.03 \\
(-0.96)\end{array}$ & $\begin{array}{c}0.00 \\
(0.42)\end{array}$ & $\begin{array}{l}-0.01 \\
(-0.66)\end{array}$ & & \\
\hline Constant & & & & & $\begin{array}{l}46.8^{\mathrm{a}} \\
(6.80)\end{array}$ & $\begin{array}{l}22.9^{\mathrm{a}} \\
(3.65)\end{array}$ & & & & & $\begin{array}{l}60.8^{\mathrm{a}} \\
(6.74)\end{array}$ & $\begin{array}{l}23.8^{\mathrm{a}} \\
(8.80)\end{array}$ \\
\hline No. of cities & 31 & 31 & 31 & 31 & 31 & 31 & 31 & 31 & 31 & 31 & 31 & 31 \\
\hline Sample size & 78 & 60 & 78 & 60 & 78 & 60 & 79 & 60 & 79 & 60 & 79 & 60 \\
\hline$R^{2}$ within & 0.12 & 0.00 & 0.09 & 0.00 & & & 0.32 & 0.05 & 0.32 & 0.04 & & \\
\hline$R^{2}$ between & 0.00 & 0.03 & 0.27 & 0.03 & & & 0.04 & 0.01 & 0.05 & 0.01 & & \\
\hline$R^{2}$ overall & 0.01 & 0.01 & 0.20 & 0.02 & 0.19 & 0.01 & 0.04 & 0.01 & 0.13 & 0.01 & 0.13 & 0.01 \\
\hline Hausman test: $\chi^{2}(2)$ & & & 5.50 & 0.13 & & & & & 5.15 & 2.40 & & \\
\hline Hausman test: $\operatorname{Pr}>\chi^{2}$ & & & 0.07 & 0.94 & & & & & 0.07 & 0.30 & & \\
\hline
\end{tabular}

${ }^{\mathrm{a}}$ Unavailability of schools measured by percent of children who attend school in the evening. Incentives proxy $=1$ if annual changes in shared and own revenues have the same sign, and $=0$ otherwise. $T$-statistics are in parentheses. ${ }^{a}$ and ${ }^{c}$ denotes significance at 1 and $10 \%$ levels, respectively. 
of incentives, for a given amount of expenditures. The difference in infant mortality rates between the groups with better and worse fiscal incentives on average is equal to about 9.9 deaths out of 10,000 born (which is equal to $5 \%$ of the average in the whole sample). The difference in percentages of school children who have to go to school in the evening between the two groups on average is equal to 1.6 (5.3\% of the average in the whole sample). To produce robust results, I use instrumental variables as well as fixed and random effects. The results are robust across specifications. The results of Table 5 support the view that with weaker fiscal incentives the local governments spend the money less efficiently.

Table 6 presents results of the estimation of Eq. (10) for two sub-samples based on the value of the incentives proxy. The coefficient on public expenditures is much higher and more significant for the sub-sample with better fiscal incentives if we control for city differences by using specification with random effects. The point estimate of coefficient $\rho$ of the logarithm of health care expenditures per capita in regression (1) of Table 6 , with infant mortality as independent variable and sub-sample where incentives proxy is unity, is -2.50 with a $t$-statistic of -1.85 . The point estimate of the same parameter in the same regression on the sub-sample with zero incentives proxy is equal to zero with zero $t$-statistic. The results of analogous regressions of percentage of children attending schools in the evening gives point estimate for $\rho$ of -8.98 (with $-4.11 t$-statistic) for better incentives sub-sample, and -1.12 (with $-0.68 t$-statistic) for worse incentives sub-sample. This provides further evidence consistent with the view that with harder budget constraints for local governments, spending is more efficient and, therefore, the real impact of each ruble spent is higher.

To summarize, the results of Tables 3-6 are the following. Firstly, fiscal incentives of local politicians in Russia are very weak; indeed, on average, they are non-existent, since changes in own revenues are almost entirely offset by changes in shared revenues. Secondly, the number of businesses formed depends positively on the strength of fiscal incentives. And thirdly, the strength of fiscal incentives positively affects the efficiency of public spending.

\section{Robustness check}

In this section, I discuss the robustness of the results described above. One may believe that wealthy cities experience increases in their revenues, have efficient public goods provision and profitable growing enterprises, and so do not need subsidies. In contrast, poor cities have to spend a lot on subsidies and experience both decline in revenues and poor public goods provision. This story may be an alternative explanation for the results presented in Tables 4-6. In that case, the results would be driven by the presence of wealthy cities in the group with good fiscal incentives. This is a serious concern because there are eight times more observations with both shared and own revenues going up (wealthy cities) than 
observations with both shared and own revenues going down (poor cities) in the group with good fiscal incentives, so it may be the case that on average the effect of wealthy cities dominates. To test against this alternative interpretation of the results, I exclude the wealthy cities from the sample and repeat the analysis presented above.

I split the sample into four groups: the first group, including 31 observations, for which shared revenues decreased and own revenues increased; the second group contains 29 observations, for which shared revenues increased and own revenues decreased; the third group consists of 71 observations with changes in both shared and own revenues positive; and the fourth group includes observations for which shared and own revenues declined. There are only eight observations in group 4.

According to the incentive story told in Section 3, groups 4 and 3 should have better fiscal incentives then groups 1 and 2 . This partition coincides with the definition of the incentives proxy variable used for the analysis above. Hypotheses II and III predict that observations in either the third or the fourth group should have more favorable private business environment and more efficient spending on public goods than observations in either group 1 or group 2 . In particular, it should be true for the fourth group. If that is the case, the alternative interpretation of results in Tables 4-6 can be rejected. The alternative interpretation says that only poor cities experience declines in revenues and inefficient public goods provision.

Unfortunately, this robustness check of the results presented in Table 4 is statistically impossible due to small sample problem. This is because there are only five observations in the fourth group for the variable measuring new business formation. ${ }^{64}$ So, furthermore, I concentrate on discussing the robustness check of the results from testing Hypothesis III only.

Firstly, for a very crude robustness check, I plot infant mortality and percentage of children attending schools in the evening in Fig. 1. This check is very crude because we do not control for any variables that influence measures of the quantity of public goods provision other then the group itself.

As shown in Fig. 1, as expected the third group medians of both measures of public goods provision are below the medians of groups 1 and 2. The fourth group medians are the highest of all, however. This may be due to a small sample problem (since there are only eight observations in this group), or it can be related to the fact that in city-year combinations of group 4, cities have experienced an economic depression which both resulted in loss of revenues for the government and in a general depression in the public sector. If this result reverses when

\footnotetext{
${ }^{64}$ Unlike other variables, the new business formation variable can be constructed only for capitalcities of their regions. However, if we ignore the small sample problem and compare the medians of the four groups (they are $0.09,-0.18,2.08$, and -1.19 , respectively), we would conclude that the robustness check is failed. However, this is a very weak conclusion since it is based only on five observations.
} 
Definition of the groups ( $x$ axis):

group 1 - shared revenues decreased; own revenues increased;

\# of obs.

group 2 - shared revenues increased; own revenues decreased;

31

group 3 - both shared and own revenues increased;

group 4 - both shared and own revenues decreased.

8

Group medians are highlighted on the figures

Infant mortality rate by group:

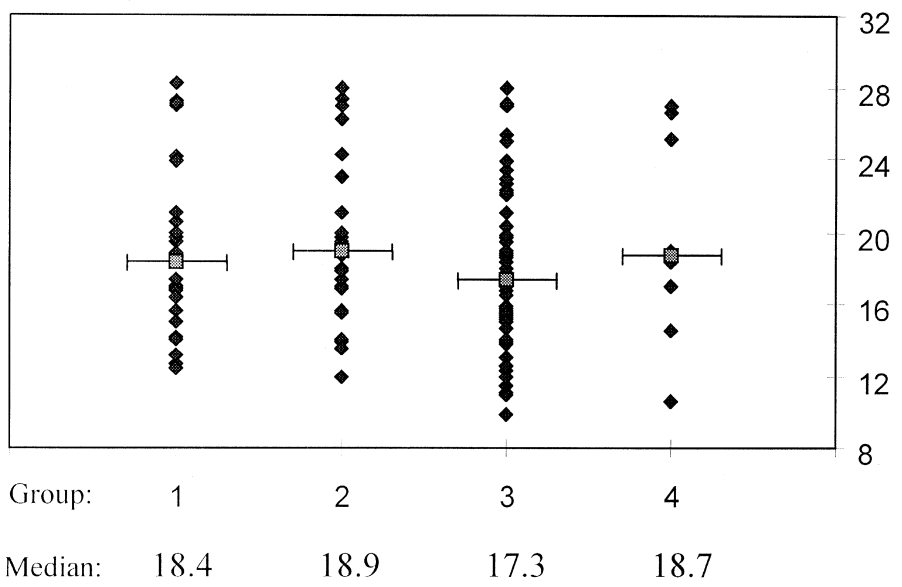

Children, attending school in the evening by group:

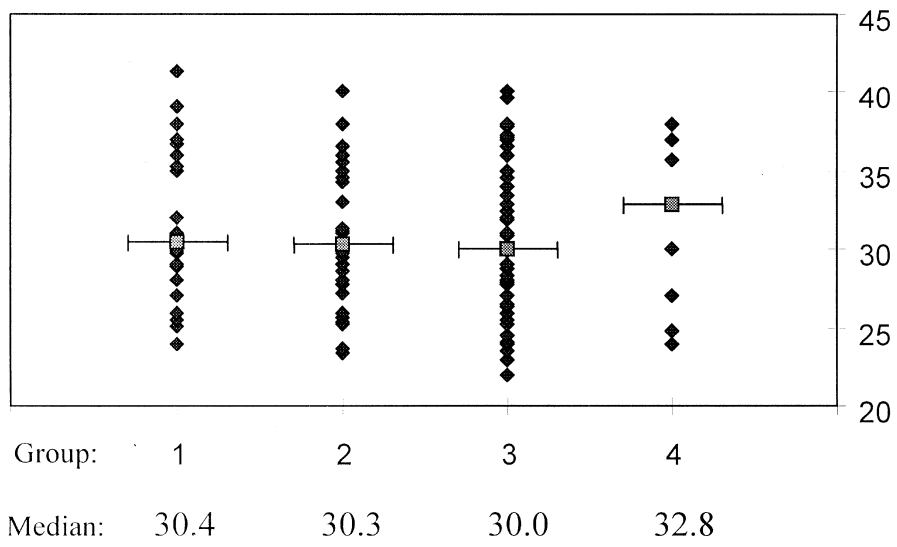

Fig. 1. Infant mortality and children attending schools in the evening by group. 
Table 7

Robustness check: sub-sample excluding observations with both changes in shared and own revenues positive

\begin{tabular}{|c|c|c|c|c|c|c|}
\hline \multirow[t]{2}{*}{ Dependent variable } & \multicolumn{3}{|c|}{ Infant mortality } & \multicolumn{3}{|c|}{ Unavailability of schools } \\
\hline & (1) & (2) & (3) & (4) & $(5)$ & (6) \\
\hline Groups & 1,4 & 2,4 & $1,2,4$ & 1,4 & 2,4 & $1,2,4$ \\
\hline Incentives proxy & $\begin{array}{l}-1.54^{\mathrm{b}} \\
(-2.20)\end{array}$ & $\begin{array}{l}-0.78 \\
(-1.57)\end{array}$ & $\begin{array}{l}-1.25^{\mathrm{a}} \\
(-2.68)\end{array}$ & $\begin{array}{l}-2.36 \\
(-1.54)\end{array}$ & $\begin{array}{c}0.48 \\
(0.31)\end{array}$ & $\begin{array}{l}-1.32 \\
(-1.00)\end{array}$ \\
\hline $\begin{array}{l}\text { Log of health care expend. } \\
\text { per capita }\end{array}$ & $\begin{array}{c}0.45 \\
(0.71)\end{array}$ & $\begin{array}{c}0.49 \\
(0.67)\end{array}$ & $\begin{array}{c}0.33 \\
(0.83)\end{array}$ & & & \\
\hline $\begin{array}{l}\text { Log of education expend. } \\
\text { per capita }\end{array}$ & & & & $\begin{array}{l}-0.04 \\
(-0.02)\end{array}$ & $\begin{array}{c}0.25 \\
(0.11)\end{array}$ & $\begin{array}{l}-0.61 \\
(-0.46)\end{array}$ \\
\hline No. of cities & 25 & 26 & 31 & 25 & 26 & 31 \\
\hline Sample size & 39 & 37 & 68 & 39 & 37 & 68 \\
\hline$R^{2}$ within & 0.32 & 0.26 & 0.18 & 0.29 & 0.01 & 0.06 \\
\hline$R^{2}$ between & 0.01 & 0.01 & 0.01 & 0.01 & 0.00 & 0.01 \\
\hline$R^{2}$ overall & 0.01 & 0.06 & 0.01 & 0.01 & 0.01 & 0.01 \\
\hline Hausman test: $\chi^{2}(2)$ & 0.95 & 0.00 & 0.31 & 2.89 & 0.30 & 1.45 \\
\hline Hausman test: $\operatorname{Pr}>\chi^{2}$ & 0.62 & 1.00 & 0.85 & 0.24 & 0.85 & 0.48 \\
\hline
\end{tabular}

${ }^{a}$ Unavailability of schools measured by percent of children who attend school in the evening. Incentives proxy $=1$ if annual changes in shared and own revenues have the same sign, and $=0$ otherwise. Random effects specification used. $T$-statistics are in parentheses. ${ }^{\mathrm{a}}$ and ${ }^{\mathrm{b}}$ denote significance at 1 and 5\% levels, respectively. Definitions of groups: group $1-$ shared $\downarrow$ and own $\uparrow$; group $2-$ shared $\uparrow$ and own $\downarrow$; group $3-$ shared $\uparrow$ and own $\uparrow$; group $4-$ shared $\downarrow$ and own $\downarrow$.

controlling for city-specific random effects, which presumably are correlated with negative economic shocks, then the alternative explanation can still be rejected.

In Table 7, I present the results of a random effects regression of real measures of public goods provision on the logarithm of corresponding to public expenditures per capita for the sub-samples excluding group 3. The results are not always significant because the sample size is very small for these regressions; however, the results support the incentive story. In five out of six regressions, the sign of the effect of the incentives proxy is correct: higher incentives produce lower infant mortality (significant at 5\%) and a lower percentage of children studying in the evening even when we exclude group 3. However, for school availability, the results are insignificant (the $t$-statistic is at most 1.54) and in one regression the sign is wrong but insignificant.

To summarize, the effect of the incentives proxy on infant mortality is robust to the sample selection that excludes observations for which all sources of revenues increased. The effect of incentives proxy on the measure of school availability has the right sign for the comparison of groups 1 and 4 and has a wrong sign for a comparison of groups 2 and 4 (both comparisons are insignificant). The right sign appears when groups 1 and 2 are put together. Overall, the story of incentives passes the robustness check.

One may think that the city status should not change over time and most of the variation should come from the differences between cities. However, 15 out of 35 
cities in my sample have switched between better and worse incentives groups more than once. This may be related to the fact that over the period of 6 years (from 1992 to 1997) there have been many political changes in the cities. For example, the fact that mayors and governors have changed may explain why many cities switched groups.

\section{Conclusions}

One of Russia's major problems is its structure of inter-governmental relations. The main finding of this paper is that Russian localities never became financially independent from the regional governments. Local officials have not been given sufficient responsibility for their decisions on expenditures and have not been granted the right to raise their own revenues. This paper provides some evidence that revenue sharing relations between local and regional governments hinder local government's incentives for providing infrastructure for private business development. In addition, it shows that the fiscal dependence of local governments on the regions has a negative effect on the efficiency of local public goods provision.

The point this paper is making is that economic reform needs to be supported by the reform of governmental institutions that would align the interests of businessmen, citizens and government officials. This is particularly vital at the local level.

This paper sheds some light on the ongoing debate of why some countries undertaking economic reforms grow faster than others and why Russia is in the slow growth group.

My conclusions also have implications for the theory of decentralization: shifts in expenditures towards higher decentralization will not achieve the expected benefits without a concurrent shift in control towards localities over how much revenue local governments can collect.

\section{Acknowledgements}

The earlier version of the paper is a part of my doctoral thesis at Harvard University. I am especially grateful to my main advisor Andrei Shleifer for his guidance, support, many comments and very helpful discussions. I have also benefited greatly from discussions and suggestions of Alberto Alesina and David Cutler. I am indebted to Yingyi Qian and Daniel Treisman for comments and constructive criticisms. I thank Michael Alexeev, Robert Conrad, Sergei Guriev, Galina Kurliandskaya, Jim Leitzel, Ellen Meara, Gerard Roland, Jeffrey Wurgler, and the participants of the Organizations seminar at Harvard University for lots of comments. I thank the League of Russian Cities for their help with data collection. Financial support from the Economics Education and Research Consortium is gratefully acknowledged. 


\section{Appendix A. Revenues, expenditures and intergovernmental transfers of different levels of government in Russia in 1996}

\begin{tabular}{|c|c|c|c|c|c|c|}
\hline & \multicolumn{3}{|c|}{$\mathrm{R}$ trillion } & \multirow{2}{*}{\multicolumn{3}{|c|}{$\begin{array}{l}\text { Distribution between the levels } \\
\text { of consolidated budget }\end{array}$}} \\
\hline & \multirow[t]{2}{*}{ Federal } & \multirow[t]{2}{*}{ Regional } & \multirow[t]{2}{*}{ Local } & & & \\
\hline & & & & Federal & Regional & Local \\
\hline Tax revenues & 218.7 & 120.1 & 134.1 & $46.2 \%$ & $25.4 \%$ & $28.4 \%$ \\
\hline Total revenues & 281.6 & 138.0 & 148.2 & $49.6 \%$ & $24.3 \%$ & $26.1 \%$ \\
\hline Expenditures net of transfer ${ }^{a}$ & 271.6 & 147.3 & 187.5 & $44.8 \%$ & $24.3 \%$ & $30.9 \%$ \\
\hline $\begin{array}{l}\text { Surplus before transfer, } \mathrm{R} \text { trill- } \\
\text { ion }\end{array}$ & 9.9 & -9.3 & -39.3 & $3.7 \%$ & $-6.3 \%$ & $-20.9 \%$ \\
\hline $\begin{array}{l}\text { and } \% \text { of expenditures net of } \\
\text { transfer }\end{array}$ & & & & & & \\
\hline Deficit financing (net surplus) & -29.0 & -9.7 & 0.0 & $75.0 \%$ & $25.0 \%$ & $0.0 \%$ \\
\hline $\begin{array}{l}\text { Net transfer, } R \text { trillion and } \% \text { of } \\
\text { tax revenues }\end{array}$ & 38.9 & 0.4 & -39.3 & $17.8 \%$ & $0.3 \%$ & $-29.3 \%$ \\
\hline
\end{tabular}

${ }^{a}$ Expenditures net of transfers $=$ total revenues - transfer-deficit financing. 1997 average dollar exchange rate is 5600 rubles per dollar. Source: Ministry of Finance of Russian Federation.

\section{Appendix B. Descriptive statistics}

\begin{tabular}{|c|c|c|c|c|c|c|c|}
\hline Variable $^{\mathrm{a}}$ & Units & $\begin{array}{l}\text { No. of } \\
\text { obs }\end{array}$ & Median & Mean & S.E. & Min & $\operatorname{Max}$ \\
\hline Population & $\#, 1000$ & 139 & 486 & 601.9 & 36.8 & 12 & 1430 \\
\hline Total expenditures & $\mathrm{R}, \mathrm{mm}$ & 139 & $599,863.0$ & $886,981.5$ & $65,227.2$ & 10,519 & $3,087,459$ \\
\hline Own revenues & $\mathrm{R}, \mathrm{mm}$ & 139 & $77,441.2$ & $148,972.7$ & $15,960.8$ & 277 & $1,007,639$ \\
\hline Shared revenues & $\mathrm{R}, \mathrm{mm}$ & 139 & $540,121.1$ & $746,242.8$ & $53,203.7$ & 10,195 & $2,714,642$ \\
\hline Annual change in own revenues & $\mathrm{R}, \mathrm{mm}$ & 139 & $12,486.5$ & $35,678.9$ & $10,521.4$ & $-599,073$ & 652,332 \\
\hline Annual change in shared revenues & $\mathrm{R}, \mathrm{mm}$ & 139 & $35,221.6$ & $63,532.9$ & $19,118.0$ & $-805,040$ & 884,602 \\
\hline Annual change in expenditures & $\mathrm{R}, \mathrm{mm}$ & 139 & $57,380.8$ & $115,321.9$ & $18,955.8$ & $-475,644$ & 811,551 \\
\hline Incentives proxy & \#, binomial & 139 & 1 & 0.56 & 0.08 & 0 & 1 \\
\hline Education spending per capita & $\mathrm{R}, 1000$ & 139 & 269.8 & 301.7 & 8.6 & 63.8 & 582.9 \\
\hline Health care spending per capita & $\mathrm{R}, 1000$ & 138 & 221.3 & 231.7 & 7.0 & 28.9 & 444.3 \\
\hline Infant mortality & $1 / 1000$ & 139 & 18.0 & 18.5 & 0.4 & 9.9 & 28.2 \\
\hline $\begin{array}{l}\text { Kids, attending schools in the even- } \\
\text { ing }\end{array}$ & $\%$ & 139 & 30.0 & 30.8 & 0.4 & 22 & 41.3 \\
\hline New business formation (regional) & $\#, 1000$ & 112 & 1.03 & 0.21 & 0.42 & -11.6 & 13.4 \\
\hline Number of businesses (regional) & $\#, 1000$ & 144 & 7.53 & 9.49 & 0.68 & 1.6 & 32.2 \\
\hline
\end{tabular}

a 1997 average dollar exchange rate is 5600 rubles per dollar. All nominal variables in constant prices of 1997. Incentives proxy $=1$ in 79 observations and $=0$ in 60 observations. 


\section{Appendix C}

$$
\max _{P, B, S} c P+B+S \quad \text { s.t. } \quad P+S \leq \bar{T}+(1+\alpha) g(P) y(B)
$$

Assumptions:
A1. $g(P) y(B)-$ concave w.r.t. $P$ and $B$, i.e. $\left(g^{\prime} y^{\prime}\right)^{2}<g y g^{\prime \prime} y^{\prime \prime} ; g^{\prime \prime}(P)<0 ; y^{\prime \prime}(B)<0$.
A2. $g^{\prime}(P)>0 ; y^{\prime}(B)<0$.
A3. $0<c<1 ;-1 \leq \alpha \leq 0$.
A4. $P \geq 0 ; B \geq 0 ; S \geq 0$.

Denote the Lagrange multiplier of $(*)$ by $\lambda$.

F.O.C. for (*):

$$
\begin{aligned}
& \text { If } \lambda>1 \text {, then } \quad \text { If } \lambda=1 \text {, then } \\
& S=0 \\
& \text { (i) } \quad S>0 \\
& P=\bar{T}+(1+\alpha) g(P) y(B) \\
& \text { (ii) } S+P=\bar{T}+(1+\alpha) g(P) y(B) \\
& c-\lambda+\lambda(1+\alpha) g^{\prime}(P) y(B)=0 \\
& \text { (iii) } c-1+(1+\alpha) g^{\prime}(P) y(B)=0 \\
& 1+\lambda(1+\alpha) g(P) y^{\prime}(B)=0 \\
& \text { (iv) } 1+\lambda(1+\alpha) g(P) y^{\prime}(B)=0
\end{aligned}
$$

(i)-(viii) define $B^{*}, S^{*}, P^{*}$.

\section{Proposition 1.}

$$
\forall \alpha: \frac{\mathrm{d} B^{*}}{\mathrm{~d} \alpha}<0
$$

Proof of Proposition 1:

$$
(\text { vii }),(\text { viii }) \Rightarrow \frac{\mathrm{d} B^{*}}{\mathrm{~d} \alpha}=\frac{y^{\prime}\left(\frac{g^{\prime 2}}{g^{\prime \prime}}-g\right)}{(1+\alpha)\left(g y^{\prime \prime}-\frac{g^{\prime 2} y^{\prime 2}}{g^{\prime \prime} y}\right)}<0
$$

\section{Proposition 2.}

$\forall \alpha: \frac{\mathrm{d} P^{*}}{\mathrm{~d} \alpha}>0$

Proof of Proposition 2

$$
\text { (vi),(viii) } \Rightarrow \frac{\mathrm{d} P^{*}}{\mathrm{~d} \alpha}=-\frac{g^{\prime} g\left(y^{\prime 2}-y^{\prime \prime}\right)}{(1+\alpha)\left(g y g^{\prime \prime} y^{\prime \prime}-\left(g^{\prime} y^{\prime}\right)^{2}\right)}>0 \text {. }
$$




\section{Proposition 3.}

$$
\left.\frac{\mathrm{d} S^{*}}{\mathrm{~d} \alpha}\right|_{d[\bar{T}+\bar{W}]=-d\left[(1+\alpha) g^{*} y^{*}\right]}<0 .
$$

Proof of Proposition 3: by assumption $S^{*}+P^{*}$ is constant and by Proposition 2, $P^{*}$ is increasing in $\varphi$, therefore $S^{*}$ must be decreasing in $\varphi$.

\section{References}

Arora, V.B., Norregaard, J., 1997. Intergovernmental fiscal relations: the Chinese system in perspective, IMF, Working Paper, WP/97/129.

Boycko, M., Shleifer, A., Vishny, R., 1995. Privatizing Russia, MIT Press.

European Bank for Reconstruction and Development, 1997. Transition Report, EBRD, London.

Jin, H., Qian, Y., Weingast, B.R., 1999. Regional decentralization and fiscal incentives: federalism, Chinese style, Stanford University, Working Paper, SWP-99-013.

Johnson, S., Kaufmann, D., Shleifer, A., 1997. The unofficial economy in transition. Brookings Papers on Economic Activity 2, 159-239.

Knight, J., Li, S., 1999. Fiscal decentralization: incentives, redistribution and reform in China. Oxford Development Studies 27 (1), 5-32.

Lavrov, A., 1996. Fiscal federalism and financial stabilization. Problems of Economic Transition 39 (1), 83-94.

Montinola, G., Qian, Y., Weingast, B.R., 1995. Federalism Chinese style: the political basis for economic success in China. World Politics 48 (1), 50-81.

Oi, J., 1992. Fiscal reform and the economic foundations of local state corporatism in China. World Politics 45, 99-126.

Oi, J., 1994. Rural China Takes Off: Incentives for Reform, University of California Press, Berkeley.

Qian, Y., Weingast, B.R., 1996. China's transition to markets: market-preserving federalism, Chinese style. Journal of Policy Reform 1 (2), 149-186.

Qian, Y., Weingast, B.R., 1997. Federalism as a commitment to reserving market incentives. Journal of Economic Perspectives 11 (4), 83-92.

Qian, Y., Xu, C., 1993. Why China's economic reforms differ: the M-Form hierarchy and entry/ expansion of non-state sector. Economics of Transition 1 (2), 135-170.

Parker, S., Tritt, G., Woo, W.T., 1997. Some lessons learned from the comparison of transition in Asia and Eastern Europe. In: Woo, W.T., Parker, S., Sachs, J.D. (Eds.), Economies in Transition: Comparing Asia and Eastern Europe, MIT Press.

RECEP, 1998. Russian Economic Trends, Blackwell, London, II Quarterly.

Shleifer, A., 1997. Government in transition. European Economic Review 41 (3), 385-410.

Treisman, D., 1996a. The politics of intergovernmental transfers in post-Soviet Russia. British Journal of Political Science 26, 299-335.

Treisman, D., 1996b. Fiscal redistribution in a fragile federation: Moscow and the regions in 1994, Harvard University, Mimeo.

Treisman, D., 1997. Deciphering Russia's federal finance: fiscal appeasement on 1995 and 1996, UCLA, Mimeo.

Wong, C.P. (Ed.), 1997. Financing Local Government in The People's Republic of China. 